\title{
Social Accounting Matrix on the Base of the Mexican System of National Accounting*
}

\author{
Dora Elena Ledesma-Carrión, Lidia Hernández-Hernández, María Teresa Leonor Muciño-Porras \\ Instituto Nacional de Estadística y Geografía, Ciudad de México, México
}

\begin{abstract}
Links between institutional sectors and economic activities with National Accounting System of Mexico are studied used accounting multipliers. Key sectors had changed to strategic or leading as oil and gas extraction and dairy product manufacturing, i.e., Mexico went from a producer of goods to a service provider country, losing value added in their production chains. The mixed income is leading/independent economic activity for woman whose income is between 1 and 5 minimum wages. This is really important in the domestic economy through its impact on solidarity activities: providing care and support and providing food. Moreover, non-financial corporations and households of 10 or more minimum wages for income investing in strategic sectors such as retail trade and wholesale and manufacturing products derived from oil and coal. This is evidence of two Mexicos: the traditional and industrialized.
\end{abstract}

Keywords: social accounting matrix, national accounting, linkages, accounting multipliers, input-output tableau

\section{Introduction}

Many works have been written on the application of social accounting matrix (SAM), accounting linkages and multipliers but none shows the low impact of public policies that encourage certain industries giving preferential treatment in taxes, water, electricity, etc., arguing that generate new high paying jobs and technological development of the region. Bolio, Remes, Lajous, Manyika, Roseé, and Ramirez (2014) explained that in Mexico the growth and prosperity are output of a two-speed economy (Mckinsey Global Institute, 2014). In a modern Mexico, a high-speed and technologically forward multinationals factories that compete in global markets and universities that graduate more engineers that Germany and traditional Mexico, a land of sub-scale, low-speed, technologically backward, unproductive enterprises and many of which operate in informal economy. For eight decades Mexico has been unable to grow and develop economically to substantially improve the living standards of its population. The free trade in North America has come to break the production chains. This is evident in the study of direct, cross, and cyclical multipliers. The important oil

\footnotetext{
* Project Supported: Modelo de equilibrio general computable para el caso de México (Computable general equilibrium model for the case of Mexico).

Dora Elena Ledesma-Carrión, Ph.D., researcher, Instituto Nacional de Estadística y Geografía (INEGI), Ciudad de México, México.

Lidia Hernández-Hernández, master in engineering, assistant researcher, Instituto Nacional de Estadística y Geografía (INEGI), Ciudad de México, México.

María Teresa Leonor Muciño-Porras, degree in actuarial, General Directorate of Administration, Instituto Nacional de Estadística y Geografía (INEGI), Ciudad de México, México.

Correspondence concerning this article should be addressed to Dora Elena Ledesma-Carrión, Researcher, DG Deputy Research, Instituto Nacional de Estadística y Geografía (INEGI), Patriotismo 711 Torre A, Ciudad de México 03730, México.
} 
industry impacts poorly homes, also the automotive industry with Original Equipment manufactures (OEMs) and indirect jobs linked to it have no impact on economic development. This is evident in the study of direct, cross, and cyclical multipliers.

This paper shows these two Mexicos by building a social accounting matrix similar to that proposed by Thorbecke and Jung (1996), in terms of branches of economic activity and applying the theory of Leontief multipliers (Thorbecke, 2000). In section 2 provides a brief review of the SAMs for Mexico published in recent years ago. In section 3 the methodology used for this analysis is established. In section 4 the results of the major multipliers are presented in the direct-indirect-cyclic sequence. In section 5 the analysis is done and the results are discussed. Finally, sections 6 and 7 give the conclusions and references.

\section{State of the Art}

The latest SAMs, this proposal by Núñez (2015) focused on analyzing taxes on the extraction of hydrocarbons using a general equilibrium model. In Mexico oil derivatives are very expensive because of these taxes. Other works of Núñez (2008) evaluated social policies to alleviate poverty disaggregating household income by deciles. Multisectoral model is used incorporating input-output tableau (IOT) in 2000. This tableau is obtained from the 1980 data using the biproportional matrix transformation or Row-Column Adjustment of Successive-approaches (RAS) method. Pineda (2011) worked on a social accounting matrix (SAM, 2003) based on the system of national accounting of Mexico (SNCM, 2014), but it does not transform to Thorbecke (2000) form, i.e., from balance equations system to factors, agents, and accounts matrix arrangement. In that work financial and social policies were evaluated, the results evidence weak linkage between financial sector and real economy (structure weak of financial system). Intermediaries and financial markets do not contribute to the economy strongly. Núñez (2008) proposed a SAM-MX00 for Mexico on the base of the first three accounts (good \& services, production, and generation of income), capital, and good \& services with outside accounts of the SNCM, year 2000. Institutional sectors took account the gross operating surplus for enterprises and wage and contributions for household. Gross mixed income was not considered. The capital account was in terms of saving/investment (it is an inequality). The other accounts were not used (primary allocated, secondary distribution and use income, and financial). The SAM-MX00 was disaggregated into 43 accounts: 10 household deciles, 18 productive activities, three public goods, and other 12 accounts: companies, government with three kinds of taxes, two kinds of transfers, a savings/investment accounts, productive factors labor and capital, private consumption, and rest of word. This structure does not consider, for example, traditional factories (tortilla, bakeries), traditional and high-speed factories (tequila, breweries, bakeries, and chocolate), and technological forward factories (auto parts, OEMs, and steelmakers).

Kim Kijong (2008) studied the multiplier effects of a hypothetical new sector to change the social accounting matrix. The new sector is assigned a composite of factors by gender and skills. Furthermore, if these individuals are in the government program "Expanded public works programme”. Employment and income distribution are misleading, i.e., underestimate the impact of the proposed target level of employment.

Minzer and Solís (2014) mixed equations account balance of goods and services account to the economic activities of IOT, factors of investment and trade with the rest of the world analyzed certain tax reform measures such as the increase in value added tax in some branches of economic activity and its impact on tax collection and poverty. 
Other authors as Blancas (2006) and Laguna (2010) analyzed the inter-relationships and supply chains in Mexico. And Sobarzo (2009) discussed some proposals for tax reform. The proposal is financed through tax the new social security system. The social accounting matrix calibrates a general equilibrium model in the context of coexistence of formality and informality in the labor market.

The structure of the System of National Accounts of Mexico (SCNM) is made up of balance equations linking macroeconomic with microeconomic aspects. The SAMs to Mexico mentioned herein take into account some industry groups only, all of them broken down in terms of population deciles rather than the distribution of income-expenditure in terms of minimum wages.

The proposed social accounting matrix (SAM-MX11) is founded on complete economic structure of the system of national accounting of Mexico, year 2011 (System of National Accounting of Mexico, 2011) (SNAM-2011), MFTIS (Mexican Foreign Trade Inquiry System, 2011), and ENIGH (National Survey on Household Income and Spending, 2012). The square matrix size is 288 and showed in Table 1, it is Defourny and Thorbecke type (Defourny \& Thorbecke, 1984; Thorbecke \& Jung, 1996). The SNAM-2011 comprises balance equations and accumulation and current accounts. National accounting: goods and services (G\&S), production (P), generation of income (GI), allocation of income (PAI), distribution of income (DI), use of income (UI), capital (C), gross fixed capital formation (GFCF), financial (F), goods and services with the outside (G\&S outside). The latter account is divided: current transferences (TC) and capital transferences (TK). SNAM has institutional units: non-financial corporations (NF), financial corporations (F), government units, including social security funds (G), non-profit institutions serving households (NPIsSH), households (H), and the rest of the world (RW). Households are formed by customers and producers. The GI, PAI, DI, UI, C, and GFCF accounts were disaggregated on institutional sectors. Household sector is broken down into income-expenditure deciles or minimum salaries level (mw).

The input-output tableau (IOT-MX11) is included into SAM-MX11. The IOT-MX11 is built by economic activities added into sectors, subsectors, and branches. IOT-MX11 uses the North America industrial classification system (NAICS) code of 2007. The tableau size is 165.

The production account presents economic activities by branches. The goods and services account shows economics activities and institutional sectors.

Links between institutional sectors and economic activities with SNAM-2011 were studied by using accounting multipliers. IOT-MX11 was obtained by using the RAS method to OIT-MX 2008. Table 2 presents disaggregated IOT-MX11. Each of the aij entrances is Tij matrix of different sizes, T13 is the matrix which allocates the value added generated by the production activities into income accruing to the various factors of productions. T33 shows the intermediate input requirement, T32 reflects the expenditure pattern of the institutional sectors on the commodities which they consume. T21 shows the scanning of the factorial income distribution into institutional sectors. T22 gives the inter-institutional transfers.

The current transferences entrances were disaggregated to economic activities branches and NAFTA countries and the rest of the world. To do this, it was necessary to make the correspondence between the tariff code (Mexico Foreign Trade Inquiry System, 2015) and NAICS code (United States Census Bureau, 2014), because export and import of goods and services are not present for countries in SNAM. 
Table 1

Social Accounting Matrix (SAM) on the Base of the System of National Accounting of Mexico (SNAM)

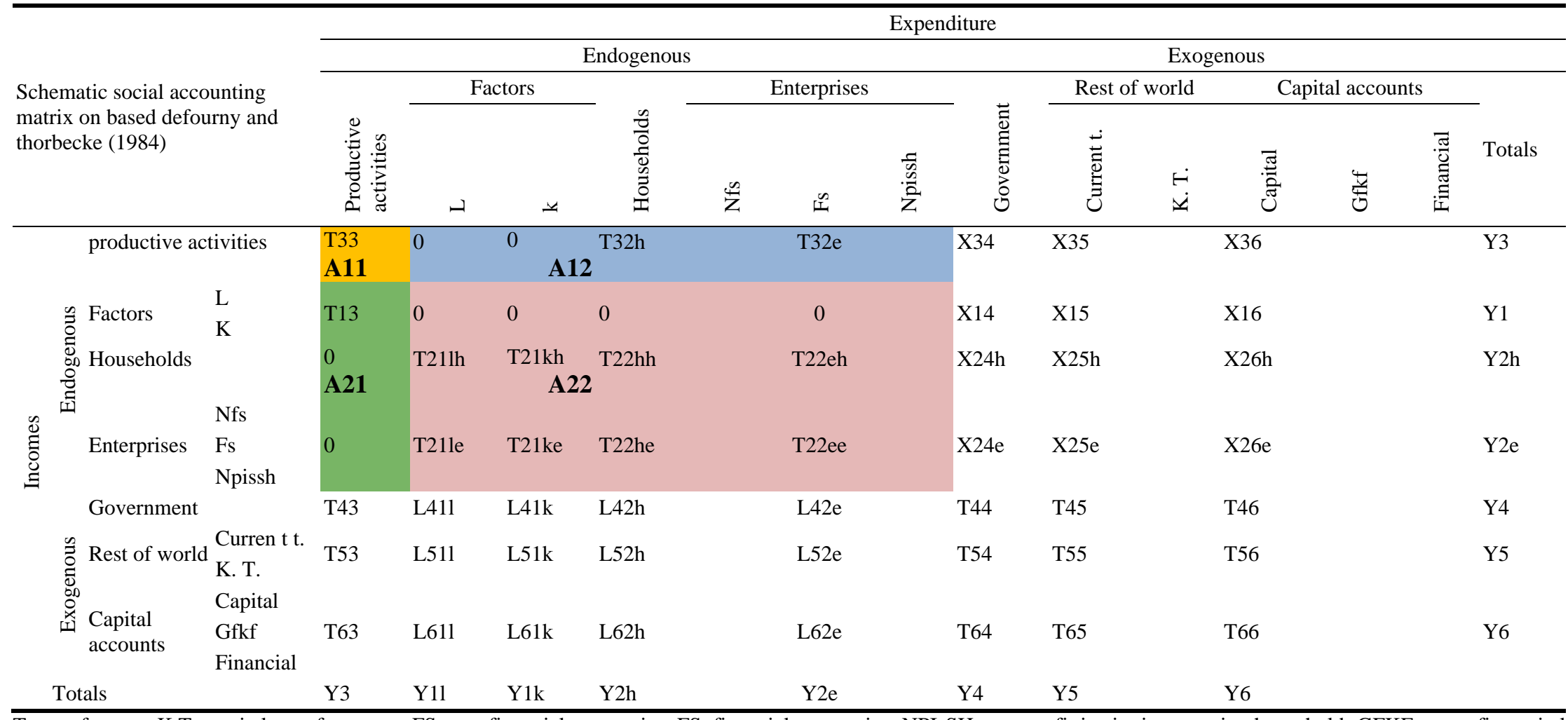

T, transference; K.T., capital transferences; nFS, non-financial companies; FS, financial companies; NPIsSH, non-profit institutions serving household; GFKF, gross fix capital formation; L, work; K, capital. 
Table 2

IOT Compounds. Matrix $165 \times 165$

\begin{tabular}{|c|c|c|c|}
\hline SECTOR & A12 - SAM aggregated $=$ OIT & NAICS code & $\begin{array}{l}\text { Number of } \\
\text { accounts }\end{array}$ \\
\hline 11 & Agriculture, hunting, forestry and fishing & $\begin{array}{l}\text { 1111-1114, 1119, 1121, 1122-1125, 1129, 1131-1133, } \\
\text { 1141, 1142, 1151-1153. }\end{array}$ & 19 \\
\hline 21 & Mining and quarrying & 2111, 2121-2123, 2131. & 5 \\
\hline 22 & Electricity, gas, and water supply & 2211, 2221, 2222. & 3 \\
\hline 23 & Construction & 23: 2361, 2362, 2371-2373, 2379, 2381-2383, 2389. & 1 \\
\hline $31-33$ & Manufacturing & $\begin{array}{l}\text { 3111-3119, 3121, 3122, 3131-3133, 3141, 3149, 3151, } \\
\text { 3152, 3159, 3161, 3162, 3169, 3211, 3212, 3219, 3221, } \\
\text { 3222, 3231, 3241, 3251-3256, 3259, 3261, 3262, } \\
\text { 3271-3274, 3279, 3311-3315, 3321-3329, 3331-3336, } \\
\text { 3339, 3341-3346, 3351-3353, 3359, 3361-3369, 3371, } \\
\text { 3372, 3379, 3391, 3399. }\end{array}$ & 86 \\
\hline $43-46$ & Commerce & 43-46: 4311 & 1 \\
\hline 48 & Transport and communications & $\begin{array}{l}\text { 4862, 4869, and the rest of the sector 48: 4811, 4812, } \\
\text { 4821, 4832, 4841, 4851-4855, 4859, 4871, 4872, 4879, } \\
\text { 4881-4885, 4889. }\end{array}$ & 3 \\
\hline 49 & Mail and storage & 49: 4911, 4921, 4931. & 1 \\
\hline 51 & Mass media information & $\begin{array}{l}\text { 51: 5111, 5112, 5121, 5122, 5151, 5152, 5171, 5172, } \\
\text { 5174, 5179, 5182, 5191. }\end{array}$ & 1 \\
\hline 52 & Financial services and of insurances & 5211, 5221-5225, 5231, 5332, 5239, 5241, 5242. & 11 \\
\hline 53 & $\begin{array}{l}\text { Real-estate and rental of personal property and } \\
\text { intangible services }\end{array}$ & 53: 5311-5313, 5321-5324, 5331. & 1 \\
\hline 54 & Professional, scientific, and technical services & 54: 5411-5419, 5511. & 1 \\
\hline 55 & Management of companies and enterprises & 55: 5511. & 1 \\
\hline 56 & Waste management and remediation services & 5621 , and the rest of the sector 56: $5611-5617,5619$. & 2 \\
\hline 61 & Educational services & 61: 6111-6117. & 1 \\
\hline 62 & Health and social care & $\begin{array}{l}6214,6216 \text {, the rest of the sub-sector } 621: 6211-6213 \text {, } \\
6215,6219 ; 6221-6223,6231-6233,6239,6241-6244 \text {. }\end{array}$ & 14 \\
\hline 71 & $\begin{array}{l}\text { Cultural and sporting services, recreation, and } \\
\text { other recreational services }\end{array}$ & 71: 7111-7115, 7121, 7131, 7132, 7139. & 1 \\
\hline 72 & $\begin{array}{l}\text { Temporary accommodation services and } \\
\text { preparation of foods and beverages }\end{array}$ & 72: 7211-7213, 7221-7224. & 1 \\
\hline 81 & Other services except government activities & $\begin{array}{l}8141 \text { and the rest of the sector 81: 8111-8114, 8121-8124, } \\
8129,8131,8132 \text {. }\end{array}$ & 2 \\
\hline \multirow[t]{2}{*}{93} & $\begin{array}{l}\text { Activities of the government and activities of } \\
\text { international organizations and offshore }\end{array}$ & 9311-9318, 9321. & 9 \\
\hline & Total & & 165 \\
\hline
\end{tabular}

The intermediate consumption and production account entrances were open to economic activities branches. The first is IOT 2011 and the second is gross production value (basic prices). The goods \& services with outside account entrances: remunerations, rental of property, and current transfers received/paid were broken down by NAFTA country redistribution like flows of Outward/Inward Direct Investment (Foreign Direct Investment, 2016).

Consumption of fixed capital (CFC), taxes less subsidies on products and adjustment by rounding are distributed as gross values added. 
Capital transferences received/paid and current transferences paid are not known. Adjustments due to changes to pension rights received/paid from/to the rest of the world (Use of income account) were adjusted few years ago. These changes were consequence of the Pension Reform in 1996.

Lending or financing and current external balance have same value but the sign changed.

The net factor income from/to the rest of the world (NFIRW), is disaggregated from the cell net added value so should be adjusted in the successive cells.

The original structure of the accounting matrix proposal is extensively explained in the paper predecessor (Ledesma-Carrión, Hernández-Hernández, \& Muciño-Porras, 2015). This SAM is in terms of the balance equations for all accounts which integrate the SCNM. The matrix here studied in terms of Thorbecke (2000) is obtained simply by rearranging and/or adding accounts.

\section{Methodology}

Accounting multipliers and linkages use Leontief theory (Thorbecke, 2000; Pineda, 2011; Núñez, 2008; Kim, 2008; Minzer \& Solís, 2014). Because revised data appear up to 2011, the SAM and OIT were calculated for 2011. Links and relations between economic sectors and branches involve the input-output tableau, the distribution by countries and industry of goods and services of imports and exports in the balance of trade (BT) and balance of payments (BP) and the relationship between institutional sectors and branches of economic activity make a system of accounting balance equations.

Data between economic and institutional sectors through SNAM were used to redistribution cell T32.

Households were open by minimum salaries levels of income and mixed income was disaggregated by sex for the first five deciles (in terms of mw) of income and not paid work is by (i) providing food, (ii) providing cleaning and maintenance of housing, (iii) providing cleaning and care of clothing and shoes, (iv) providing shopping and household management, (v) providing care and support, and (vi) providing help to other households and volunteer work. The redistributions used National Income and Expenditure Survey of Households (ENIGH [Encuesta Nacional de Ingreso y Gasto de los Hogares], 2012). The ENIGH is biannual.

The SNAM-MX11 does not provide for the production of narcotics (cannabis) in gross domestic product (GDP) and intermediate consumption (IOT-MX11) and their impact on the ENIGH. Because of this, the lower deciles are underestimated. Many families work for drug trafficking as distributers and/or producers. The families work a portion of the land for poppy and cannabis and one for beans, corn, sorghum, and other legal crops. Some of the medium and upper deciles are money lauder through their companies. The rich do not respond to interviewers, they are also underestimated.

The discrepancies between current transfers received by households (it is reported by ENIGH) and total transferences reported by BP (it is calculated with financial system data) reveal the lack of response of households.

Also, the BP does not record earnings of Mexican producers abroad, for example, Televisa, CEMEX, Bimbo, Vitro Group, etc.

The lack of registration of iron production and that was exchanged for chemicals to produce drugs, production, internal distribution, export and transfer of drugs, do not appear in BP and BT, in addition, trafficking in persons and smuggling of weapons appear not quantified in BP and BT.

Accounting multipliers direct $M \mathrm{a}_{1}$, cross $M \mathrm{a}_{2}$, and cyclical $M \mathrm{a}_{3}$ are defined as 


$$
\begin{aligned}
& \operatorname{Ma}_{1}=\left(\begin{array}{cc}
\left(\mathrm{I}-\mathrm{A}_{11}\right)^{-1} & 0 \\
0 & \left(\mathrm{I}-\mathrm{A}_{22}\right)^{-1}
\end{array}\right) \\
& \mathrm{Ma}_{2}=\left(\begin{array}{cc}
\mathrm{I} & \left(\mathrm{I}-\mathrm{A}_{11}\right)^{-1} \mathrm{~A}_{12} \\
\left(\mathrm{I}-\mathrm{A}_{22}\right)^{-1} \mathrm{~A}_{21} & \mathrm{I}
\end{array}\right) \\
& \mathrm{Ma}_{3}=\left(\begin{array}{cc}
\left(\mathrm{I}-\left(\mathrm{I}-\mathrm{A}_{11}\right)^{-1} \mathrm{~A}_{12}\left(\mathrm{I}-\mathrm{A}_{22}\right)^{-1} \mathrm{~A}_{21}\right)^{-1} & 0 \\
0 & \left(\mathrm{I}-\left(\mathrm{I}-\mathrm{A}_{22}\right)^{-1} \mathrm{~A}_{21}\left(\mathrm{I}-\mathrm{A}_{11}\right)^{-1} \mathrm{~A}_{12}\right)^{-1}
\end{array}\right)
\end{aligned}
$$

Direct multipliers are those which measure the interrelationship between productive activities and institutional sectors, equation (1). No mix of productive and institutional sectors. This interrelationship is a dimensionless proportionality constant.

From equation (2), the cross multipliers measure the interaction between sectors, that is, given the direct impact of an economic activity is affected by the subsequent interaction with any institutional sector and vice versa.

Cyclical multipliers are closing the cycle, equation (3): economic activity-institutional sector-economic activity. That is, given the cross-impact of economic activity and institutional sector, how it is affected by the subsequent interaction with any economic activity. The other cycle would be: institutional sector-economic activity-institutional sector.

\section{Results}

The fixed-price multiplier analysis is showed in the Tables 3-6 for key, strategic, leading, and independent activities respectively.

From Table 3, the GI impact has two items: the gross operating surplus (GOS) and wage and salaries, of non-financial companies and household for deciles 1-6 (current transferences), for the deciles 7-10 the impact is in PIA, DI, and UI accounts: remunerations, current transferences, rental of properties, and saving. The government supports housing credit through financial institutions: publics, Housing Fund for Institute for Social Security and Services for State Workers (FOVISSSTE) and Institute of National Housing Fund for Workers (INFONAVIT)) and privates. Also, the government supports programs for entrepreneurs and self-employment. The population with income between deciles 2 and 9 is benefited with these programs. The "Crusade against hunger" program is aimed at people in the income decile 1.

The wholesale trade \& retail trade and the real estate and rental and leasing are more impactful than oil and gas extraction and petroleum and coal products manufacturing production respect to the gross value of production (GVP). Mexico has become a trade and service country and does not remain as producer of goods. The strength of the domestic economy was slaughtered to maintain stable macroeconomic variable by free trade agreements (FTAs). The sectors 48 and 8 , transport and other services except public administration, and subsector 561, administrative and support services were benefited during this change. The sectors of electric power generation, transmission and distribution, basic chemical manufacturing, bakeries and tortilla manufacturing, animal slaughtering and processing, oilseed and grain farming, and dairy product manufacturing become traditional. The information sector growth is due to technological development. 
Table 3

Key Institutional and Economic Sectors

\begin{tabular}{|c|c|c|c|}
\hline $\begin{array}{l}\text { Variable } \\
\text { code }\end{array}$ & $\begin{array}{l}\text { Standardized } \\
\text { forward } \\
\text { linkages }\end{array}$ & $\begin{array}{l}\text { Standardized } \\
\text { backward } \\
\text { linkages }\end{array}$ & Name \\
\hline 43-46 & 5.875 & 1.100 & Wholesale trade \& Retail trade \\
\hline 3241 & 3.980 & 1.053 & Petroleum and coal products manufacturing \\
\hline REST 561 & 3.649 & 1.267 & THE REST OF THE SUB-SECTOR 561: administrative and support services \\
\hline REST 48 & 3.578 & 1.411 & THE REST OF THE SECTOR 48: transportation \\
\hline L w\&s S10 & 3.162 & 1.119 & $\begin{array}{l}\text { Wage and salaries }+ \text { effective employer contribution for pension }+ \text { effective employer } \\
\text { contribution for nonpension }+ \text { imputed contribution by employers for pension }+ \text { imputed } \\
\text { contribution by employers for nonpension. Household with } 10 \text { minimum salaries }\end{array}$ \\
\hline 51 & 2.722 & 1.147 & Information \\
\hline 2211 & 2.620 & 1.154 & Electric power generation, transmission and distribution \\
\hline 54 & 2.605 & 1.040 & Professional, scientific, and technical services \\
\hline 3116 & 2.141 & 1.348 & Animal slaughtering and processing \\
\hline 72 & 1.826 & 1.151 & Accommodation and food services \\
\hline L w\&s S9 & 1.783 & 1.119 & $\begin{array}{l}\text { Wage and salaries }+ \text { effective employer contribution for pension }+ \text { effective employer } \\
\text { contribution for nonpension }+ \text { imputed contribution by employers for pension }+ \text { imputed } \\
\text { contribution by employers for nonpension. Household with } 9 \text { minimum salaries }\end{array}$ \\
\hline 3118 & 1.744 & 1.237 & Bakeries and tortilla manufacturing \\
\hline REST 81 & 1.692 & 1.139 & THE REST OF THE SECTOR 81: other services (except public administration) \\
\hline H DI S10 & 1.672 & 1.208 & Household with 10 minimum salaries. Distribution of income \\
\hline 3121 & 1.671 & 1.234 & Beverage manufacturing \\
\hline 3361 & 1.590 & 1.107 & Motor vehicle manufacturing \\
\hline L w\&s S8 & 1.549 & 1.119 & $\begin{array}{l}\text { Wage and salaries }+ \text { effective employer contribution for pension }+ \text { effective employer } \\
\text { contribution for nonpension }+ \text { imputed contribution by employers for pension }+ \text { imputed } \\
\text { contribution by employers for nonpension. Household with } 8 \text { minimum salaries }\end{array}$ \\
\hline K NPIsSH & 1.486 & 1.151 & $\begin{array}{l}\text { Gross operating suplus + consumption of fix capital. Non-profit institutions serving } \\
\text { household }\end{array}$ \\
\hline 5221 & 1.485 & 1.027 & Depository credit intermediation \\
\hline L w\&s S7 & 1.382 & 1.119 & $\begin{array}{l}\text { Wage and salaries }+ \text { effective employer contribution for pension }+ \text { effective employer } \\
\text { contribution for nonpension }+ \text { imputed contribution by employers for pension }+ \text { imputed } \\
\text { contribution by employers for nonpension. Household with } 7 \text { minimum salaries }\end{array}$ \\
\hline
\end{tabular}

From Table 4, the rental of properties of nFS is the economic activity which is more strategic. It is following for FS and NFIRW. The GVP of petroleum and coal products manufacturing, plastics product manufacturing and resin, synthetic rubber and synthetic thread, and filaments manufacturing are strategic. The current transferences of nFS and the rental of properties of FS are strategic activities whereas households are key activities. The intermediate consumption of manufacturing of petroleum and coal, basic chemical, motor vehicle parts and resin, synthetic rubber, synthetic thread, and filaments are averagely strategic.

From Table 5, the more intensive leading economic activities are the manufacturing of pharmaceutical and medicine, dairy products, animal food, sugar and confectionery products, other food, iron and steel mills and ferroalloy, other crop farming and cattle ranching, and farming in production and intermediate consumption.

The wages and salaries of household decile 2 of income and financial companies and the effective employer contribution for non-pension of non-financial companies are linked to construction sector like leading activity. 
Table 4

Strategic Institutional and Economic Sectors

\begin{tabular}{|c|c|c|c|}
\hline $\begin{array}{l}\text { Variable } \\
\text { code }\end{array}$ & $\begin{array}{l}\text { Standardized } \\
\text { forward } \\
\text { linkages }\end{array}$ & $\begin{array}{l}\text { Standardized } \\
\text { backward } \\
\text { linkages }\end{array}$ & Name \\
\hline $\mathrm{K} n \mathrm{nS}$ & 15.267 & 0.223 & Gross operating suplus + consumption of fix capital. Non-financial companies \\
\hline H API S10 & 5.967 & 0.887 & Household with 10 minimum salaries. Primary allocation of income \\
\hline 53 & 5.868 & 0.931 & Real estate and rental and leasing \\
\hline H UI S10 & 5.169 & 0.967 & Household with 10 minimum salaries. Use of income \\
\hline H API S9 & 3.264 & 0.887 & Household with 9 minimum salaries. Primary allocation of income \\
\hline 3251 & 3.206 & 0.858 & Basic Chemical Manufacturing \\
\hline H UI S9 & 2.843 & 0.967 & Household with 9 minimum salaries. Use of income \\
\hline H API S8 & 2.806 & 0.887 & Household with 8 minimum salaries. Primary allocation of income \\
\hline 2111 & 2.757 & 0.937 & Oil and gas extraction \\
\hline H API S7 & 2.478 & 0.887 & Household with 7 minimum salaries. Primary allocation of income \\
\hline H UI S8 & 2.448 & 0.967 & Household with 8 minimum salaries. Use of income \\
\hline H UI S7 & 2.166 & 0.967 & Household with 7 minimum salaries. Use of income \\
\hline H API S6 & 2.022 & 0.887 & Household with 6 minimum salaries. Primary allocation of income \\
\hline 3363 & 1.892 & 0.910 & Motor vehicle parts manufacturing \\
\hline E FS PAI & 1.836 & 0.767 & Enterprises. Financial companies. Primary allocation of income \\
\hline H UI S6 & 1.774 & 0.967 & Household with 6 minimum salaries. Use of income \\
\hline 1111 & 1.712 & 0.730 & Oilseed and grain farming \\
\hline H API S5 & 1.656 & 0.887 & Household with 5 minimum salaries. Primary allocation of income \\
\hline E FS UI & 1.590 & 0.571 & Enterprises. Financial companies. Use of income \\
\hline H UI S5 & 1.459 & 0.967 & Household with 5 minimum salaries. Use of income \\
\hline
\end{tabular}

Table 5

\section{Leading Institutional and Economic Sectors}

\begin{tabular}{|c|c|c|c|}
\hline $\begin{array}{l}\text { Variable } \\
\text { code }\end{array}$ & $\begin{array}{l}\text { Standardized } \\
\text { forward } \\
\text { linkages }\end{array}$ & $\begin{array}{l}\text { Standardized } \\
\text { backward } \\
\text { linkages }\end{array}$ & Name \\
\hline H DI S9 & 0.997 & 1.208 & Household with 9 minimum salaries. Distribution of income \\
\hline 3113 & 0.965 & 1.282 & Sugar and confectionery product manufacturing \\
\hline L w\&s S5 & 0.963 & 1.119 & $\begin{array}{l}\text { Wage and salaries + effective employer contribution for pension }+ \text { effective employer } \\
\text { contribution for nonpension }+ \text { imputed contribution by employers for pension }+ \text { imputed } \\
\text { contribution by employers for nonpension. Household with } 5 \text { minimum salaries }\end{array}$ \\
\hline 1123 & 0.946 & 1.335 & Poultry and egg production \\
\hline 3314 & 0.908 & 1.116 & Nonferrous metal (except Aluminum) production and processing \\
\hline 2221 & 0.888 & 1.121 & Water collection, treatment and supply of water \\
\hline H DI S8 & 0.882 & 1.208 & Household with 8 minimum salaries. Distribution of income \\
\hline 3256 & 0.861 & 1.120 & Soap, cleaning compound, and toilet preparation manufacturing \\
\hline 61 & 0.856 & 1.443 & Educational services \\
\hline 5241 & 0.846 & 1.082 & Insurance carriers \\
\hline 3152 & 0.834 & 1.033 & Cut and sew apparel manufacturing \\
\hline H DI S7 & 0.800 & 1.208 & Household with 7 minimum salaries. Distribution of income \\
\hline 5224 & 0.784 & 1.241 & Securities and commodity contracts intermediation and brokerage \\
\hline 3231 & 0.781 & 1.073 & Printing and related support activities \\
\hline 3211 & 0.769 & 1.194 & Sawmills and wood preservation \\
\hline
\end{tabular}


Table 5 continued

\begin{tabular}{llll}
\hline $\begin{array}{l}\text { Variable } \\
\text { code }\end{array}$ & $\begin{array}{l}\text { Standardized Standardized } \\
\text { forward } \\
\text { linkages }\end{array}$ & $\begin{array}{l}\text { backward } \\
\text { linkages }\end{array}$ & Name \\
\hline L w\&s S4 & 0.729 & 1.119 & $\begin{array}{l}\text { Wage and salaries + effective employer contribution for pension + effective employer } \\
\text { contribution for nonpension + imputed contribution by employers for pension + imputed } \\
\text { contribution by employers for nonpension. Household with } 4 \text { minimum salaries }\end{array}$ \\
3272 & 0.701 & 1.042 & $\begin{array}{l}\text { Glass and glass product manufacturing } \\
\text { Agencies, brokerages, and other insurance related activities }\end{array}$ \\
L GMI S9 & 0.690 & 1.083 & $\begin{array}{l}\text { Gross mix income. Household with 9 minimum salaries } \\
71\end{array}$ \\
\hline
\end{tabular}

Secondly, financial sector has leading activities through of management of companies and enterprises, securities and commodity contracts intermediation and brokerage, non-depository credit intermediation, and insurance carriers.

Thirdly, the mixed income for sex and kind of activity impact likes leading economic branch: providing care and support for woman for deciles 3, 2, 4, 1, and 5, in this order. It follows the provided food for woman for deciles 5-1. The NPIsSH are led by imputed contribution by employers for non-pension.

From Table 6, the GVP of grain and oilseed milling, educational services, plastic product manufacturing, and insurance carriers are the strongest independent activities.

Table 6

Independent Institutional and Economic Sectors

\begin{tabular}{|c|c|c|c|}
\hline $\begin{array}{l}\text { Variable } \\
\text { code }\end{array}$ & $\begin{array}{l}\text { Standardized } \\
\text { forward } \\
\text { linkages }\end{array}$ & $\begin{array}{l}\text { Standardized } \\
\text { backward } \\
\text { linkages }\end{array}$ & Name \\
\hline H API S3 & 0.918 & 0.887 & Household with 3 minimum salaries. Primary allocation of income \\
\hline 3253 & 0.915 & 0.870 & Pesticide, fertilizer, and other agricultural chemical manufacturing \\
\hline 3344 & 0.908 & 0.627 & Semiconductor and other electronic component manufacturing \\
\hline 3399 & 0.870 & 0.786 & Other miscellaneous manufacturing \\
\hline H UI S3 & 0.824 & 0.967 & Household with 3 minimum salaries. Use of income \\
\hline 1113 & 0.797 & 1.000 & Fruit and tree nut farming \\
\hline 3132 & 0.794 & 0.806 & Fabric mills \\
\hline 2123 & 0.746 & 0.950 & Nonmetallic mineral mining and quarrying \\
\hline 3359 & 0.740 & 0.673 & Other electrical equipment and component manufacturing \\
\hline 3259 & 0.724 & 0.651 & Other chemical product and preparation manufacturing \\
\hline 3329 & 0.701 & 0.681 & Other fabricated metal product manufacturing \\
\hline 3328 & 0.686 & 0.951 & Coating, engraving, heat treating, and allied activities \\
\hline 1133 & 0.682 & 0.978 & Logging \\
\hline 3255 & 0.665 & 0.997 & Paint, coating, and adhesive manufacturing \\
\hline H API S2 & 0.653 & 0.887 & Household with 2 minimum salaries. Primary allocation of income \\
\hline E FS DI & 0.644 & 0.811 & Enterprises. Financial companies. Distribution of income \\
\hline 3342 & 0.624 & 0.647 & Communications equipment manufacturing \\
\hline 3336 & 0.616 & 0.669 & Engine, turbine, and power transmission equipment manufacturing \\
\hline 3341 & 0.613 & 0.611 & Computer and peripheral equipment manufacturing \\
\hline 3122 & 0.597 & 0.954 & Tobacco manufacturing \\
\hline
\end{tabular}

The import and export subsidies into GI account are government independent activities. The rental of property of non-financial companies is an intensive independent activity. Primary activities do not appear as independent 
except other animal production. Many secondly and thirdly are independent as water collection, treatment, and supply of water; steel product manufacturing from purchased steel; paint, coating, and adhesive manufacturing; iron and steel mills and ferroalloy manufacturing, general public administration, regulating and promoting economic development, administrative activities of social welfare institutions, among other activities.

The first 10 economic activities with direct multipliers more intensives and OEMs activities are showed in Table 7: 2122 Metal ore mining, Rest 48 Transportation except pipeline, 5224 Securities and commodity contracts intermediation and brokerage, 5232 Securities and commodity exchanges, 2221 Water collection, treatment and supply of water, 55 Management of companies and enterprises, 3241 Petroleum and coal products manufacturing, 9318 National security activities, 3113 Sugar and confectionery product manufacturing, 3118 Bakeries and tortilla manufacturing, 3361 Motor vehicle manufacturing, 3363 Motor vehicle parts manufacturing and 3362 Motor vehicle body and trailer manufacturing, 3161 Leather and hide tanning and finishing, 3162 Footwear manufacturing.

From Tables 7-9, taking the activity more direct multiplier value, metal ore mining, this affects to petroleum and coal products manufacturing by a factor of 0.12820 . This same activity has a maximum cross multiplier factor 0.09061 with capital of non-financial corporations, 0.00786 with property income of households with $10+\mathrm{mw}$ and 0.00327 with the wages and salaries of these same households. For gross mixed income of household with $10+$ mw the factor is 0.00599 .

In the case of cyclical multipliers of that same economic activity the factor is 0.00155 for the petroleum and coal products manufacturing, 0.00199 for transportation except pipeline, and 0.00444 for real estate and rental and leasing.

Other activity that represents modern Mexico is motor vehicle manufacturing. This has direct multipliers of 0.50802 and 0.26277 for motor vehicle parts manufacturing and wholesale trade \& retail trade respectively. Cross multipliers are $0.06078,0.00783$, and 0.00345 with capita of non-financial companies, rental of property for household with income of $10+\mathrm{mw}$ and gross mixed income of same households, and cyclical multipliers: 0.00432, 0.00193, and 0.00150 for real estate and rental and leasing, transportation except pipeline and petroleum, and coal products manufacturing respectively.

Economic activities representative of modern and traditional Mexico are bakeries and tortilla manufacturing. The maximum direct impacts are 0.33837 (1111, oilseed and grain farming), 0.20812 (43-46, wholesale trade \& retail trade), 0.18531 (3112, grain and oilseed milling), 0.07422 (3251, basic chemical manufacturing), and 0.05384 (3241, petroleum and coal products manufacturing).

Table 7

Direct Multipliers

\begin{tabular}{llllllllll}
\hline Row code & 2122 & Row code & REST 48 & Row code & 5224 & Row code & 5232 & Row code & 2221 \\
\hline 2122 & 2.81522 & REST 48 & 2.23917 & 5224 & 2.20312 & 5232 & 2.15328 & 2221 & 2.13249 \\
3241 & 0.12820 & 3241 & 0.46336 & 55 & 0.20338 & 51 & 0.37448 & 3251 & 0.29299 \\
2211 & 0.12491 & 2111 & 0.20490 & 54 & 0.14080 & 54 & 0.15131 & $43-46$ & 0.11251 \\
REST 561 & 0.10129 & $43-46$ & 0.10891 & REST 561 & 0.13048 & 5221 & 0.10358 & 2111 & 0.07843 \\
$43-46$ & 0.08611 & 3363 & 0.07065 & 51 & 0.09606 & 55 & 0.07683 & 3241 & 0.06265 \\
3259 & 0.06605 & 54 & 0.06033 & 53 & 0.08736 & REST 561 & 0.07334 & 54 & 0.04706 \\
2111 & 0.06184 & REST 561 & 0.05624 & REST 48 & 0.08195 & $43-46$ & 0.05559 & REST 48 & 0.02988 \\
53 & 0.05510 & 53 & 0.03477 & 2211 & 0.05744 & 53 & 0.04664 & 3399 & 0.02748 \\
54 & 0.05305 & 3251 & 0.02472 & $43-46$ & 0.04260 & 2211 & 0.03625 & REST 561 & 0.02089 \\
\hline
\end{tabular}


Table 7 continued

\begin{tabular}{|c|c|c|c|c|c|c|c|c|c|}
\hline Row code & 2122 & Row code & REST 48 & Row code & 5224 & Row code & 5232 & Row code & 2221 \\
\hline 3251 & 0.03626 & 3336 & 0.02412 & 3241 & 0.03543 & REST 81 & 0.03622 & 2211 & 0.02000 \\
\hline REST 48 & 0.01975 & REST 81 & 0.02304 & 3221 & 0.02961 & 3221 & 0.03473 & 3273 & 0.01715 \\
\hline REST 81 & 0.01899 & 55 & 0.02208 & REST 81 & 0.02786 & 3344 & 0.03423 & 3259 & 0.01672 \\
\hline 51 & 0.01736 & 51 & 0.02156 & 3231 & 0.02629 & 3231 & 0.02975 & REST 81 & 0.01621 \\
\hline 5241 & 0.01560 & 2211 & 0.01689 & 5221 & 0.02514 & 3241 & 0.01818 & 53 & 0.01349 \\
\hline 3339 & 0.01319 & 5221 & 0.01305 & 5241 & 0.02396 & REST 48 & 0.01347 & 55 & 0.01279 \\
\hline 55 & 0.01260 & 5241 & 0.01289 & 2111 & 0.01782 & 5241 & 0.01197 & 51 & 0.01254 \\
\hline 5221 & 0.01250 & 72 & 0.01247 & 72 & 0.01607 & 72 & 0.01160 & 3329 & 0.00742 \\
\hline 2221 & 0.01084 & 3262 & 0.00881 & 3251 & 0.01417 & 3251 & 0.01078 & 2123 & 0.00705 \\
\hline Row code & 55 & Row code & 3241 & Row code & 9318 & Row code & 3113 & Row code & 3118 \\
\hline 55 & 2.12420 & 3241 & 2.11919 & 9318 & 2.11087 & 3113 & 2.10616 & 3118 & 2.10600 \\
\hline 54 & 0.11245 & 2111 & 0.92665 & 3241 & 0.13989 & 1119 & 0.49673 & 1111 & 0.33837 \\
\hline REST 561 & 0.06915 & 3251 & 0.05325 & 2111 & 0.06906 & $43-46$ & 0.15598 & $43-46$ & 0.20812 \\
\hline 53 & 0.03600 & $43-46$ & 0.04731 & $43-46$ & 0.06137 & 3241 & 0.07637 & 3112 & 0.18531 \\
\hline 3241 & 0.02553 & 55 & 0.02637 & 3251 & 0.04860 & REST 561 & 0.06967 & 3251 & 0.07422 \\
\hline 51 & 0.02411 & REST 48 & 0.02212 & 72 & 0.04253 & 3112 & 0.05688 & 3241 & 0.05384 \\
\hline 5221 & 0.01836 & 3327 & 0.01314 & 2211 & 0.04239 & 3251 & 0.05576 & REST 561 & 0.04011 \\
\hline 2111 & 0.01150 & REST 561 & 0.00978 & 51 & 0.03806 & 2111 & 0.04282 & 3261 & 0.03903 \\
\hline $43-46$ & 0.00883 & 54 & 0.00825 & REST 48 & 0.02067 & 3261 & 0.04157 & REST 48 & 0.03674 \\
\hline 72 & 0.00776 & 5221 & 0.00582 & 54 & 0.01986 & 2211 & 0.03922 & 2111 & 0.03630 \\
\hline 5224 & 0.00736 & 2211 & 0.00546 & REST 561 & 0.01978 & 54 & 0.03633 & 53 & 0.03183 \\
\hline 2211 & 0.00697 & 53 & 0.00380 & 3329 & 0.01636 & 3119 & 0.03478 & 2211 & 0.02859 \\
\hline REST 48 & 0.00678 & 51 & 0.00367 & 3328 & 0.01553 & 3253 & 0.03168 & 3113 & 0.02484 \\
\hline 3231 & 0.00332 & 5224 & 0.00217 & REST 81 & 0.01399 & REST 48 & 0.03130 & 3119 & 0.01965 \\
\hline REST 81 & 0.00319 & 72 & 0.00212 & 3359 & 0.00893 & 53 & 0.02940 & 3253 & 0.01869 \\
\hline 3221 & 0.00313 & 3329 & 0.00173 & 2221 & 0.00852 & 3222 & 0.02828 & 54 & 0.01847 \\
\hline 5241 & 0.00299 & 3312 & 0.00164 & 3363 & 0.00775 & 1113 & 0.02684 & 3222 & 0.01695 \\
\hline 3251 & 0.00254 & 3324 & 0.00150 & 53 & 0.00669 & 3115 & 0.02402 & 3115 & 0.01526 \\
\hline Row code & 3361 & Row code & 3362 & Row code & 3363 & Row code & 3161 & Row code & 3162 \\
\hline 3361 & 1.88403 & 3362 & 1.72453 & 3363 & 1.79472 & 3161 & 1.55610 & 3162 & 1.80840 \\
\hline 3363 & 0.50802 & 3311 & 0.30809 & $43-46$ & 0.12197 & 3116 & 0.40348 & 3161 & 0.26009 \\
\hline $43-46$ & 0.26277 & $43-46$ & 0.17409 & 3311 & 0.06858 & $43-46$ & 0.18958 & $43-46$ & 0.18872 \\
\hline 3261 & 0.07505 & 3363 & 0.08211 & 3344 & 0.06290 & REST 561 & 0.10090 & 3116 & 0.08535 \\
\hline REST 48 & 0.06192 & REST 561 & 0.05585 & 3359 & 0.06041 & 1121 & 0.06697 & REST 561 & 0.06910 \\
\hline 3312 & 0.06191 & 3313 & 0.04665 & 3261 & 0.05803 & 1123 & 0.06331 & 3262 & 0.05634 \\
\hline 3262 & 0.05102 & 3312 & 0.04442 & REST 561 & 0.05761 & 3251 & 0.04916 & 3252 & 0.04546 \\
\hline REST 561 & 0.04613 & REST 48 & 0.04408 & 3312 & 0.04263 & 2211 & 0.03607 & 2211 & 0.03531 \\
\hline 3311 & 0.04069 & 2211 & 0.03862 & 3329 & 0.03791 & 3371 & 0.03446 & 3251 & 0.03384 \\
\hline 3336 & 0.03775 & 3255 & 0.03792 & 3314 & 0.03663 & 3111 & 0.03313 & 3241 & 0.02801 \\
\hline 3359 & 0.02656 & 3241 & 0.03589 & REST 48 & 0.03405 & REST 48 & 0.03182 & 53 & 0.02626 \\
\hline 2211 & 0.02628 & 2122 & 0.03288 & 3353 & 0.03364 & 3241 & 0.03098 & REST 48 & 0.02438 \\
\hline 3241 & 0.02539 & 54 & 0.03171 & 3251 & 0.03056 & 1122 & 0.02848 & 54 & 0.02290 \\
\hline 3252 & 0.02533 & 3251 & 0.02705 & 3252 & 0.02954 & 1111 & 0.02710 & 3222 & 0.02267 \\
\hline 3362 & 0.02503 & 3332 & 0.02262 & 2211 & 0.02929 & 2111 & 0.02202 & 3132 & 0.02220 \\
\hline 53 & 0.02424 & 53 & 0.02115 & 54 & 0.02543 & 53 & 0.02102 & 2111 & 0.01805 \\
\hline 3251 & 0.02359 & 3211 & 0.02107 & 53 & 0.02482 & 1129 & 0.01876 & 3255 & 0.01674 \\
\hline 3328 & 0.02220 & 2111 & 0.02027 & 3313 & 0.02298 & 54 & 0.01703 & 1121 & 0.01419 \\
\hline
\end{tabular}


Table 8

Cross Multipliers

\begin{tabular}{|c|c|c|c|c|c|c|c|c|c|}
\hline Row code & 2122 & Row code & REST 48 & Row code & 5224 & Row code & 5232 & Row code & 2221 \\
\hline 2122 & 1.00000 & REST 48 & 1.00000 & 5224 & 1.00000 & 5232 & 1.00000 & 2221 & 1.00000 \\
\hline $\mathrm{K} n \mathrm{nFS}$ & 0.09061 & $\mathrm{~K}$ nFS & 0.13264 & $\mathrm{~K} n \mathrm{nF}$ & 0.11249 & $\mathrm{~K} n \mathrm{nFS}$ & 0.15336 & $\mathrm{~K} n \mathrm{nFS}$ & 0.09416 \\
\hline H API S10 & 0.00786 & H API S10 & 0.03994 & H API S10 & 0.01838 & K NPIsSH & 0.01406 & H API S10 & 0.02963 \\
\hline E FS PAI & 0.00703 & L w\&s S10 & 0.02959 & H UI S10 & 0.01193 & H API S10 & 0.01300 & L w\&s S10 & 0.02377 \\
\hline L GMI S10 & 0.00599 & H UI S10 & 0.02558 & L w\&s S10 & 0.01011 & E FS PAI & 0.01043 & H UI S10 & 0.01898 \\
\hline K FS & 0.00544 & H API S9 & 0.02109 & H API S9 & 0.00971 & H UI S10 & 0.00865 & H API S9 & 0.01565 \\
\hline H UI S10 & 0.00526 & H API S8 & 0.01789 & H API S8 & 0.00823 & L GMI S10 & 0.00858 & H API S8 & 0.01327 \\
\hline E FS UI & 0.00453 & L w\&s S9 & 0.01562 & E FS PAI & 0.00798 & K FS & 0.00808 & L w\&s S9 & 0.01255 \\
\hline H API S9 & 0.00415 & H API S7 & 0.01560 & H API S7 & 0.00718 & H API S9 & 0.00687 & H API S7 & 0.01158 \\
\hline H API S8 & 0.00352 & H UI S9 & 0.01351 & L GMI S10 & 0.00664 & E FS UI & 0.00672 & L w\&s S8 & 0.01065 \\
\hline L w\&s S10 & 0.00327 & L w\&s S8 & 0.01325 & H UI S9 & 0.00630 & H API S8 & 0.00583 & H UI S9 & 0.01002 \\
\hline L GMI S9 & 0.00316 & H API S6 & 0.01242 & K FS & 0.00618 & H API S7 & 0.00508 & L w\&s S7 & 0.00929 \\
\hline H API S7 & 0.00307 & L w\&s S7 & 0.01156 & H API S6 & 0.00572 & H UI S9 & 0.00457 & H API S6 & 0.00922 \\
\hline H UI S9 & 0.00278 & H UI S8 & 0.01146 & K NPIsSH & 0.00554 & L GMI S9 & 0.00453 & H UI S8 & 0.00850 \\
\hline L GMI S8 & 0.00268 & H UI S7 & 0.00999 & H UI S8 & 0.00534 & H API S6 & 0.00405 & H UI S7 & 0.00742 \\
\hline H API S6 & 0.00244 & H API S5 & 0.00987 & L w\&s S9 & 0.00534 & H UI S8 & 0.00387 & L w\&s S6 & 0.00739 \\
\hline H UI S8 & 0.00235 & K NPIsSH & 0.00987 & E FS UI & 0.00514 & L GMI S8 & 0.00384 & H API S5 & 0.00732 \\
\hline L GMI S7 & 0.00234 & L w\&s S6 & 0.00920 & H UI S7 & 0.00466 & H UI S7 & 0.00338 & E FS PAI & 0.00693 \\
\hline Row code & 55 & Row code & 3241 & Row code & 9318 & Row code & 3113 & Row code & 3118 \\
\hline 55 & 1.00000 & 3241 & 1.00000 & 9318 & 1.00000 & 3113 & 1.00000 & 3118 & 1.00000 \\
\hline K nFS & 0.20802 & $\mathrm{~K}$ nFS & 0.02114 & L w\&s S10 & 0.10822 & $\mathrm{~K} n \mathrm{nFS}$ & 0.06776 & $\mathrm{~K}$ nFS & 0.10905 \\
\hline H API S10 & 0.03138 & H API S10 & 0.00450 & H API S10 & 0.10012 & H API S10 & 0.01678 & H API S10 & 0.02048 \\
\hline H UI S10 & 0.02039 & H UI S10 & 0.00290 & H UI S10 & 0.06310 & L w\&s S10 & 0.01160 & H UI S10 & 0.01323 \\
\hline K NPIsSH & 0.02030 & L w\&s S10 & 0.00267 & L w\&s S9 & 0.05715 & H UI S10 & 0.01078 & L w\&s S10 & 0.01146 \\
\hline H API S9 & 0.01657 & H API S9 & 0.00237 & H API S9 & 0.05287 & H API S9 & 0.00886 & H API S9 & 0.01082 \\
\hline E FS PAI & 0.01406 & K NPIsSH & 0.00221 & L w\&s S8 & 0.04848 & H API S8 & 0.00751 & K NPIsSH & 0.00962 \\
\hline H API S8 & 0.01405 & H API S8 & 0.00201 & H API S8 & 0.04485 & H API S7 & 0.00655 & H API S8 & 0.00917 \\
\hline L w\&s S10 & 0.01360 & H API S7 & 0.00176 & L w\&s S7 & 0.04228 & L w\&s S9 & 0.00613 & H API S7 & 0.00800 \\
\hline H API S7 & 0.01226 & H UI S9 & 0.00153 & H API S7 & 0.03912 & H UI S9 & 0.00569 & E FS PAI & 0.00744 \\
\hline L GMI S10 & 0.01155 & E FS PAI & 0.00142 & L w\&s S6 & 0.03367 & H API S6 & 0.00522 & H UI S9 & 0.00699 \\
\hline K FS & 0.01089 & L w\&s S9 & 0.00141 & H UI S9 & 0.03332 & L w\&s S8 & 0.00520 & H API S6 & 0.00637 \\
\hline H UI S9 & 0.01077 & H API S6 & 0.00140 & H API S6 & 0.03115 & H UI S8 & 0.00483 & L GMI S10 & 0.00613 \\
\hline H API S6 & 0.00976 & H UI S8 & 0.00130 & H UI S8 & 0.02827 & E FS PAI & 0.00473 & L w\&s S9 & 0.00605 \\
\hline H UI S8 & 0.00913 & L w\&s S8 & 0.00120 & L w\&s S5 & 0.02675 & L w\&s S7 & 0.00453 & H UI S8 & 0.00593 \\
\hline E FS UI & 0.00907 & L GMI S10 & 0.00116 & H API S5 & 0.02474 & K NPIsSH & 0.00439 & K FS & 0.00577 \\
\hline H UI S7 & 0.00796 & H UI S7 & 0.00113 & H UI S7 & 0.02465 & H UI S7 & 0.00421 & H UI S7 & 0.00517 \\
\hline H API S5 & 0.00775 & H API S5 & 0.00111 & H DI S10 & 0.02172 & H API S5 & 0.00415 & L w\&s S8 & 0.00513 \\
\hline Row code & 3361 & Row code & 3362 & Row code & 3363 & Row code & 3161 & Row code & 3162 \\
\hline 3361 & 1.00000 & 3362 & 1.00000 & 3363 & 1.00000 & 3161 & 1.00000 & 3162 & 1.00000 \\
\hline $\mathrm{K} n \mathrm{nFS}$ & 0.06078 & $\mathrm{~K}$ nFS & 0.04820 & $\mathrm{~K} n \mathrm{nF}$ & 0.03167 & $\mathrm{~K} n \mathrm{nF}$ & 0.03822 & $\mathrm{~K} n \mathrm{nFS}$ & 0.06144 \\
\hline H API S10 & 0.00783 & H API S10 & 0.01851 & H API S10 & 0.00962 & H API S10 & 0.01083 & H API S10 & 0.02741 \\
\hline H UI S10 & 0.00512 & L w\&s S10 & 0.01466 & L w\&s S10 & 0.00729 & L w\&s S10 & 0.00760 & L w\&s S10 & 0.02305 \\
\hline K NPIsSH & 0.00489 & H UI S10 & 0.01181 & H UI S10 & 0.00616 & H UI S10 & 0.00694 & H UI S10 & 0.01747 \\
\hline E FS PAI & 0.00418 & H API S9 & 0.00977 & H API S9 & 0.00508 & H API S9 & 0.00572 & H API S9 & 0.01448 \\
\hline H API S9 & 0.00414 & H API S8 & 0.00829 & H API S8 & 0.00431 & H API S8 & 0.00485 & H API S8 & 0.01228 \\
\hline H API S8 & 0.00351 & L w\&s S9 & 0.00774 & L w\&s S9 & 0.00385 & H API S7 & 0.00423 & L w\&s S9 & 0.01217 \\
\hline
\end{tabular}


Table 8 continued

\begin{tabular}{llllllllll}
\hline Row code & 2122 & Row code & REST 48 & Row code & 5224 & Row code & 5232 & Row code & 2221 \\
\hline L GMI S10 & 0.00345 & H API S7 & 0.00723 & H API S7 & 0.00376 & L w\&s S9 & 0.00401 & H API S7 & 0.01071 \\
K FS & 0.00324 & L w\&s S8 & 0.00657 & L w\&s S8 & 0.00327 & K NPIsSH & 0.00382 & L w\&s S8 & 0.01032 \\
H API S7 & 0.00306 & H UI S9 & 0.00624 & H UI S9 & 0.00325 & H UI S9 & 0.00366 & H UI S9 & 0.00922 \\
L w\&s S10 & 0.00287 & H API S6 & 0.00576 & H API S6 & 0.00299 & L w\&s S8 & 0.00340 & L w\&s S7 & 0.00900 \\
H UI S9 & 0.00270 & L w\&s S7 & 0.00573 & L w\&s S7 & 0.00285 & H API S6 & 0.00337 & H API S6 & 0.00853 \\
E FS UI & 0.00270 & H UI S8 & 0.00529 & H UI S8 & 0.00276 & H UI S8 & 0.00311 & H UI S8 & 0.00782 \\
H API S6 & 0.00244 & H UI S7 & 0.00461 & H UI S7 & 0.00241 & L w\&s S7 & 0.00297 & L w\&s S6 & 0.00717 \\
H UI S8 & 0.00229 & H API S5 & 0.00457 & H API S5 & 0.00238 & H UI S7 & 0.00271 & H UI S7 & 0.00682 \\
H UI S7 & 0.00200 & L w\&s S6 & 0.00456 & L w\&s S6 & 0.00227 & H API S5 & 0.00268 & H API S5 & 0.00677 \\
H API S5 & 0.00194 & K NPIsSH & 0.00411 & E FS PAI & 0.00223 & E FS PAI & 0.00258 & H DI S10 & 0.00595 \\
\hline
\end{tabular}

Table 9

Cyclical Multipliers

\begin{tabular}{|c|c|c|c|c|c|c|c|c|c|}
\hline Row code & 2122 & Row code & REST 48 & Row code & 5224 & Row code & 5232 & Row code & 2221 \\
\hline 53 & 0.00444 & 53 & 0.02161 & 53 & 0.01008 & 53 & 0.00731 & 53 & 0.01604 \\
\hline REST 48 & 0.00199 & 3241 & 0.00752 & REST 48 & 0.00451 & REST 48 & 0.00327 & REST 48 & 0.00717 \\
\hline 3241 & 0.00155 & 3116 & 0.00719 & 3241 & 0.00351 & 3241 & 0.00254 & 3241 & 0.00558 \\
\hline 3116 & 0.00148 & $43-46$ & 0.00674 & 3116 & 0.00335 & 3116 & 0.00243 & 3116 & 0.00534 \\
\hline $43-46$ & 0.00138 & 51 & 0.00616 & $43-46$ & 0.00314 & $43-46$ & 0.00228 & $43-46$ & 0.00500 \\
\hline 51 & 0.00127 & 3118 & 0.00611 & 51 & 0.00287 & 51 & 0.00208 & 51 & 0.00457 \\
\hline 3118 & 0.00126 & 3361 & 0.00568 & 3118 & 0.00285 & 3118 & 0.00207 & 3118 & 0.00454 \\
\hline 3361 & 0.00117 & 3121 & 0.00554 & 3361 & 0.00265 & 3361 & 0.00192 & 3361 & 0.00421 \\
\hline 3121 & 0.00114 & 3363 & 0.00518 & 3121 & 0.00258 & 3121 & 0.00187 & 3121 & 0.00411 \\
\hline 3363 & 0.00106 & 72 & 0.00501 & 3363 & 0.00242 & 3363 & 0.00175 & 3363 & 0.00384 \\
\hline 72 & 0.00103 & 3251 & 0.00445 & 72 & 0.00234 & 72 & 0.00169 & 72 & 0.00372 \\
\hline 3251 & 0.00091 & 2111 & 0.00403 & 3251 & 0.00207 & 3251 & 0.00150 & 3251 & 0.00330 \\
\hline 2111 & 0.00083 & REST 81 & 0.00384 & 2111 & 0.00188 & 2111 & 0.00136 & 2111 & 0.00299 \\
\hline REST 81 & 0.00079 & REST 561 & 0.00357 & REST 81 & 0.00179 & REST 81 & 0.00130 & REST 81 & 0.00285 \\
\hline REST 561 & 0.00073 & 2211 & 0.00329 & REST 561 & 0.00167 & REST 561 & 0.00121 & REST 561 & 0.00265 \\
\hline 2211 & 0.00068 & 5221 & 0.00319 & 2211 & 0.00154 & 2211 & 0.00111 & 2211 & 0.00244 \\
\hline 5221 & 0.00066 & 3115 & 0.00299 & 5221 & 0.00149 & 5221 & 0.00108 & 5221 & 0.00237 \\
\hline 3115 & 0.00062 & 3254 & 0.00284 & 3115 & 0.00140 & 3115 & 0.00101 & 3115 & 0.00222 \\
\hline Row code & 55 & Row code & 3241 & Row code & 9318 & Row code & 3113 & Row code & 3118 \\
\hline 53 & 0.01723 & 53 & 0.00245 & 53 & 0.05332 & 53 & 0.00911 & 53 & 0.01118 \\
\hline REST 48 & 0.00770 & REST 48 & 0.00109 & REST 48 & 0.02385 & REST 48 & 0.00407 & REST 48 & 0.00500 \\
\hline 3241 & 0.00600 & 3116 & 0.00081 & 3241 & 0.01856 & 3241 & 0.00317 & 3241 & 0.00389 \\
\hline 3116 & 0.00573 & $43-46$ & 0.00076 & 3116 & 0.01774 & 3116 & 0.00303 & 3116 & 0.00372 \\
\hline $43-46$ & 0.00537 & 51 & 0.00070 & $43-46$ & 0.01662 & $43-46$ & 0.00284 & $43-46$ & 0.00349 \\
\hline 51 & 0.00491 & 3118 & 0.00069 & 51 & 0.01520 & 51 & 0.00260 & 51 & 0.00319 \\
\hline 3118 & 0.00487 & 3361 & 0.00064 & 3118 & 0.01508 & 3118 & 0.00258 & 3361 & 0.00294 \\
\hline 3361 & 0.00452 & 3121 & 0.00063 & 3361 & 0.01400 & 3361 & 0.00239 & 3121 & 0.00287 \\
\hline 3121 & 0.00442 & 3363 & 0.00059 & 3121 & 0.01367 & 3121 & 0.00234 & 3363 & 0.00268 \\
\hline 3363 & 0.00413 & 72 & 0.00057 & 3363 & 0.01278 & 3363 & 0.00218 & 72 & 0.00259 \\
\hline 72 & 0.00399 & 3251 & 0.00050 & 72 & 0.01236 & 72 & 0.00211 & 3251 & 0.00230 \\
\hline 3251 & 0.00355 & 2111 & 0.00046 & 3251 & 0.01097 & 3251 & 0.00187 & 2111 & 0.00209 \\
\hline 2111 & 0.00322 & REST 81 & 0.00043 & 2111 & 0.00995 & 2111 & 0.00170 & REST 81 & 0.00199 \\
\hline REST 81 & 0.00306 & REST 561 & 0.00040 & REST 81 & 0.00947 & REST 81 & 0.00162 & REST 561 & 0.00185 \\
\hline
\end{tabular}


Table 9 continued

\begin{tabular}{|c|c|c|c|c|c|c|c|c|c|}
\hline Row code & 2122 & Row code & REST 48 & Row code & 5224 & Row code & 5232 & Row code & 2221 \\
\hline REST 561 & 0.00285 & 2211 & 0.00037 & REST 561 & 0.00881 & REST 561 & 0.00150 & 2211 & 0.00170 \\
\hline 2211 & 0.00263 & 5221 & 0.00036 & 2211 & 0.00813 & 2211 & 0.00139 & 5221 & 0.00165 \\
\hline 5221 & 0.00254 & 3115 & 0.00034 & 5221 & 0.00787 & 5221 & 0.00135 & 3115 & 0.00155 \\
\hline 3115 & 0.00239 & 3254 & 0.00032 & 3115 & 0.00739 & 3115 & 0.00126 & 3254 & 0.00147 \\
\hline Row code & 3361 & Row code & 3362 & Row code & 3363 & Row code & 3161 & Row code & 3162 \\
\hline 53 & 0.00432 & 53 & 0.00998 & 53 & 0.00520 & 53 & 0.00586 & 53 & 0.01476 \\
\hline REST 48 & 0.00193 & REST 48 & 0.00446 & REST 48 & 0.00233 & REST 48 & 0.00262 & REST 48 & 0.00660 \\
\hline 3241 & 0.00150 & 3241 & 0.00347 & 3241 & 0.00181 & 3241 & 0.00204 & 3241 & 0.00514 \\
\hline 3116 & 0.00144 & 3116 & 0.00332 & 3116 & 0.00173 & 3116 & 0.00195 & 3116 & 0.00491 \\
\hline $43-46$ & 0.00135 & $43-46$ & 0.00311 & $43-46$ & 0.00162 & $43-46$ & 0.00183 & $43-46$ & 0.00460 \\
\hline 51 & 0.00123 & 51 & 0.00284 & 51 & 0.00148 & 51 & 0.00167 & 51 & 0.00421 \\
\hline 3118 & 0.00122 & 3118 & 0.00282 & 3118 & 0.00147 & 3118 & 0.00166 & 3118 & 0.00417 \\
\hline 3121 & 0.00111 & 3361 & 0.00262 & 3361 & 0.00137 & 3361 & 0.00154 & 3361 & 0.00388 \\
\hline 3363 & 0.00104 & 3121 & 0.00256 & 3121 & 0.00133 & 3121 & 0.00150 & 3121 & 0.00378 \\
\hline 72 & 0.00100 & 3363 & 0.00239 & 72 & 0.00121 & 3363 & 0.00141 & 3363 & 0.00354 \\
\hline 3251 & 0.00089 & 72 & 0.00231 & 3251 & 0.00107 & 72 & 0.00136 & 72 & 0.00342 \\
\hline 2111 & 0.00081 & 3251 & 0.00205 & 2111 & 0.00097 & 3251 & 0.00121 & 3251 & 0.00304 \\
\hline REST 81 & 0.00077 & 2111 & 0.00186 & REST 81 & 0.00092 & 2111 & 0.00109 & 2111 & 0.00276 \\
\hline REST 561 & 0.00071 & REST 81 & 0.00177 & REST 561 & 0.00086 & REST 81 & 0.00104 & REST 81 & 0.00262 \\
\hline 2211 & 0.00066 & REST 561 & 0.00165 & 2211 & 0.00079 & REST 561 & 0.00097 & REST 561 & 0.00244 \\
\hline 5221 & 0.00064 & 2211 & 0.00152 & 5221 & 0.00077 & 2211 & 0.00089 & 2211 & 0.00225 \\
\hline 3115 & 0.00060 & 5221 & 0.00147 & 3115 & 0.00072 & 5221 & 0.00087 & 5221 & 0.00218 \\
\hline 3254 & 0.00057 & 3115 & 0.00138 & 3254 & 0.00068 & 3115 & 0.00081 & 3115 & 0.00205 \\
\hline
\end{tabular}

The maximum cross impacts are 0.10905 (capital of nFS), 0.02048 (rental of property of households $10+$ $\mathrm{mw}$ ), 0.01146 and 0.00605 (households with wage, salaries and contributions and mixed income of $10+\mathrm{mw}$ ).

The maximum cyclical impacts are 0.01118 (53, real estate and rental and leasing), 0.00500 (rest 48, transportation except pipeline), 0.00389 (3241, petroleum and coal products manufacturing), and 0.00372 (3116, animal slaughtering and processing).

Economic activities representative of traditional Mexico are leather and hide tanning and finishing (3161) and footwear manufacturing (3162). This first strongly impacts to activity of animal slaughtering and processing (3116, 0.40348), wholesale trade \& retail trade (43-46, 0.18958), and administrative and support services (the rest of the sub-sector 561, 0.10090).

The economic-institutional inter-sectorial relations of this activity are with non-financial companies (0.03822), rental of property (0.01083) and wages, salaries, and contributions $(0.00760)$ of $10+\mathrm{mw}$ households.

Close the cycle the multipliers that impact to activities: real estate and rental and leasing (0.00586), transportation except pipeline (0.00262), petroleum and coal products manufacturing (0.00204), and animal slaughtering and processing (0.00195).

The second activity, footwear manufacturing, close relation to first activity (3161, 0.26009), wholesale trade \& retail trade $(0.18872)$ and animal slaughtering and processing $(0.08535)$. The maximum cross impacts are 0.06144 (capital of non-financial companies), 0.02741 and 0.02305 (rental of property and wages, salaries and contributions households with income of $10+\mathrm{mw}$ ). 
And cyclical multipliers: $0.01476,0.00660$, and 0.00514 for real estate and rental and leasing, transportation except pipeline and petroleum and coal products manufacturing respectively.

The activities of leather and hide tanning and finishing and footwear manufacturing are key sectors, while animal slaughtering and processing is strategic sector. Wholesale trade \& retail trade is leading sector and administrative and support services is independent sector.

\section{Analysis and Discussion}

With regard to poverty alleviation, Minzer and Solis (2014) concluded that increasing the value added tax including drugs from $15 \%$ to $16 \%$ of households in the first quintile of income in the agricultural sector are the most affected. It is followed by the food industry and transport services. In this analysis it is also these quintiles but also in economic activities (specifically): services related to animal breeding and production and services related to forestry, grinding grains and obtaining seeds and oils and fats, slaughter, meat packing and processing of livestock, poultry and other edible animals tourism, freight transport, etcetera. Also, successful development activities such as sugar, chocolates, and sweets, and similar direct impact on other activities such as trade, growing vegetables, and manufacture of glass and glass products. Households are dedicated to this activity using (traditional) artisanal methods which are not as successful as households with incomes above 8 minimum wages.

Gaspar Núnez (2008) believed that the SAMs are perfectible because of the inaccuracy of the database. Although only disaggregated level branch of economic activity some sectors, the RAS method introduces errors increasingly moving away from the base year. In Mexico there are only input-output matrices official for the years 1975, 1980, 2003, and 2008 obtained from surveys. But if the RAS method is adjusted each year of iteration using information from surveys, this can improve outcomes, i.e., to explain aspects of the national economy. In this paper the latter applies.

Some improvements to this paper are to introduce the breakdown in men and women with or without skills as Kim (2008) did. Currently, the databases in this area have improved methodologies in Mexico.

Because the information obtained is extensive, authors can provide the full results of the industry groups and factors disaggregated to anyone who requests it in order that the data and results can be discussed.

\section{Conclusion}

Industries either representative of modern or traditional, competitive or lagged Mexico, are not significantly contributed to the household of 9 and $10 \mathrm{mw}$ income either mixed income or wages, salaries and contributions. It is much less to households with income of 1-5 mw.

Strategic sectors as metal ore mining, petroleum and coal products manufacturing, and bakeries and tortilla manufacturing affect mainly in the capital of non-financial companies, domestic liabilities of rental of property and income of $10+$ mw of household.

After affecting institutional sectors, the leading sectors as transport (except pipeline, manufacturing of motor vehicle, motor vehicle body and trailer and motor vehicle parts) these affect on real estate and rental and leasing, and transportation (except pipeline and petroleum and manufacturing of coal products). This explains that households with income under $5 \mathrm{mw}$ do not receive profit of labor and energetic reforms or the arrival of new OEMs.

The financial sector (leading sector) is divorced of micro-companies and personal business. This sector affects to activity of management of companies and enterprises and professional, scientific, and technical services (non-traditional and low speed Mexico, households with income between 1-5 mw). 


\section{References}

Blancas, A. (2006). Interinstitutional linkage analysis: A social accounting matrix multiplier approach for the mexican economy. Economic Systems Research, 18(1), 29-59.

Bolio, E., Remes, J., Lajous, T., Manyika, J., Roseé, M., \& Ramirez, E. (2014). A tale of two Mexicos: Growth and prosperity in a two-speed economy. McKinsey \& Company. Retrieved from http://www.mckinsey.com/insights/mgi

Defourny, J., \& Thorbecke, E. (1984). Structure path analysis and multiplier descomposition within a social accounting matrix framework. The Economic Journal, 94(373), 111-136. Retrieved from http://www.jstor/stable/2232220

ENIGH [Encuesta de Ingreso y Gasto de los Hogares]. (2012). ENIGH (National Survey on household income and spending, 2012). Retrieved from http://www.inegi.org.mx/est/contenidos/proyectos/accesomicrodatos/encuestas/hogares/regulares/ enigh/2012nuevaconstruccion/

Kim, K. (2008). Hypothetical integration in a social accounting matrix and fixed price multiplier analysis. The Levy Economics Institute at Bard College. Working Paper No. 552. Retrieved from https://www.iioa.org/conferences/17th/papers/251843107_090624_103950_KIM-HYPOTHETICALINTEGRATIONWP_55 2.pdf

Laguna, C. (2010). Production chains, the backbone of the Mexican industrial clusters (Cadenas productivas, columna vertebral de los clusters industriales mexicanos). Economía Mexicana Nueva Época, 19(1), 119-170.

Ledesma-Carrión, D. E., Hernández-Hernández, L., \& Muciño-Porras, M. T. L. (2015). Social accounting matrix founded on system of national accounting: case of mexico. Asian Journal of Science and Technology, 6(6), 1487-1522. Retrieved from http://www.journalajst.com/sites/default/files/2144.pdf

Mckinsey Global Institute. (2014). A tale of two Mexicos: Growth and prosperity in a two-speed economy. McKinsey \& Company. Retrieved from http://www.mckinsey.com/insights/mgi

Mexico Foreign Trade Inquiry System. (2015). (Sistema de Información Arancelaria Vía Internet, SIAVI). Tariff and statistical information of Mexico. Import and Export of Goods and Services. Retrieved from http://www.economia-snci.gob.mx/

Minzer, R., \& Solis, V. (2014). Structural analysis of the Mexican economy: Some measures of tax reform and its impact on tax revenues and poverty (Análisis estructural de la economía mexicana: Algunas medidas de reforma fiscal y su impacto en la recaudación tributaria y la pobreza). Studies and Perspectives Serie. Retrieved from http://repositorio.cepal.org/bitstream/handle/11362/36788/LCL3783_es.pdf?sequence=1

Nuñez, G. (2015). General equilibrium model applied to Mexico and tax analysis for the extraction of hydrocarbons (Modelo de Equilibrio General aplicado para México y análisis de impuestos a la extracción de hidrocarburos). Ensayos Revista de Economía, 34(1), 35-74.

Núñez, G. (2008). Working Papers in Input-Output Economics, International Input-Output Association; WPIOX 08-001. Retrieved from http://www.iioa.org/working_papers/WPs/WPIOX08-001.pdf

OECD [Organisation for Economic Co-operation and Development]. (2016). International direct investment statistics. Foreign Direct Investment (Stocks and flows outward/inward). Retrieved from http://www.oecd-ilibrary.org/finance-and-investment/oecd-international-direct-investment-statistics_2307437x

Pineda, S. A. F. (2011). Linking sector of the Mexican economy: The financial sector and the real sector. An analysis from the perspective of social accounting matrix of Mexico 2003 (Vinculación sectorial de la economía mexicana: el sector financiero y el sector real. Un análisis desde la perspectiva de la matriz de contabilidad social de México 2003). UNAM. Facultad de Estudios Superiores Acatlán. Retrieved from http://132.248.9.195/ptb2011/octubre/0674419/Index.html

System of National Accounting of Mexico (2014) (Sistema de Cuentas Nacionales de México, SCNM). (2011). National Institute of Statistics and Geography (Instituto Nacional de Estadística y Geografía, INEGI). Retrieved from http://www.inegi.org.mx/

Sobarzo, H. (2009). Expendure multipliers within an input-output model. Econoquantum, Revista de Economía y Negocios, 6(1). Retrieved from http://revistascientificas.udg.mx/index.php/EQ/article/view/111/146

Thorbecke, E. (2000). Proceedings from IARIW'00: 26th General Conference of the International Association for Research in Income and Wealth, Cracow, Poland. Retrieved from http://www.iariw.org/papers/2000/thorbecke.pdf

Thorbecke, E., \& Jung, H.-S. (1996). A multiplier decomposition method to analyze poverty alleviation. Journal of Development Economics, 48, 279-300.

United States Census Bureau. (2014). North America Industrial Classification System, 2007. Retrieved from http://www.census.gov/eos/www/naics/ 